Joanna Jaroszewska

Włodzimierz Rembisz

\title{
Relacje czynnikowe i produktywnościowe w rolnictwie Unii Europejskiej
}

Streszczenie: W artykule przywołano uznane w ekonomice rolnictwa podejście do badania relacji czynnikowych i produktywnościowych. Określono je analitycznie, po nowemu, wychodząc z funkcji produkcji. Zanalizowano te relacje dla krajów UE implicite dla różnego poziomu gospodarczego. Celem było wykazanie, że prawidłowości związane z tymi relacjami potwierdzają się w obecnym etapie gospodarczego rozwoju krajów UE oraz cały czas są przydatnym narzędziem w procesie poznawczym. Ponadto wyjaśniają podstawy obecnych różnic występujących w rolnictwie krajów UE, szczególnie tzw. starych i nowych. Wykorzystano do tego dane RER, tym samym wskazując na ich użyteczność do analiz.

Słowa kluczowe: relacje czynników produkcji, produktywność czynników, Rachunki Ekonomiczne dla Rolnictwa (RER).

\section{Wprowadzenie}

W produkcji rolniczej i koncepcji funkcji produkcji opisującej ten proces głównymi czynnikami wytwórczymi są: praca, ziemia i kapitał. Ich wzajemne do siebie odniesienia określamy mianem relacji czynnikowych czy też technicznych. Jest to też podstawa do określania technik wytwarzania w rolnictwie. Warunkują one efektywność produkcji, także w wymiarze cząstkowym, tj. produktywności tych czynników. To z kolei jest podstawą, ceteris paribus, dla wszelkich wynikowych wielkości, jak dochody czy opłacalność produkcji. Te relacje czynnikowe w istocie są fundamentami obserwowanych na powierzchni takich zagadnień, jak np. struktura agrarna, typy produkcyjne i wiele innych klasyfikacji, np. opłacalność czy konkurencyjność. Same są też wynikiem określonych przemian zachodzących w rolnictwie, w tym procesów koncentracji i warunkujących je procesów inwestycyjnych, postępu naukowo-technicznego,

Mgr inż. Joanna Jaroszewska, Instytut Ekonomiki Rolnictwa i Gospodarki Żywnościowej - PIB, Zakład Ogólnej Ekonomiki Rolnictwa, ul. Świętokrzyska 20,00-002 Warszawa, joanna.jaroszewska@ierigz. waw.pl, ORCID: 0000-0003-3733-4082; prof. dr hab. Włodzimierz Rembisz, Instytut Ekonomiki Rolnictwa i Gospodarki Żywnościowej - PIB, Zakład Zastosowań Matematyki w Ekonomice Rolnictwa, ul. Świętokrzyska 20, 00-002 Warszawa, wlodzimierz.rembisz@ierigz.waw.pl, ORCID: 0000-0001-9941-3398. 
naturalnych trendów co do zmian w zasobach tych czynników (zmniejszanie zasobów czynnika ziemi i pracy a wzrost czynnika kapitału) oraz uwarunkowań regulacyjno-politycznych. Nie będziemy się do tego tutaj odnosić. Interesuje nas jedynie zobrazowanie występujących relacji czynnikowych w rolnictwie krajów UE w tym, przy okazji, w podziale na umowne nowe kraje trzynastki ${ }^{1}$ i stare piętnastki ${ }^{2}$. Na zróżnicowanie tych relacji czynnikowych ma wpływ wiele uwarunkowań ${ }^{3}$. Najważniejszym implicite jest rozwój gospodarczy. To przyjmujemy jako założenie ilustrowane przez wskaźnik PKB per capita. Relacje czynnikowe oczywiście, jak wynika z pierwszych zdań tego wprowadzenia, mają wpływ (występuje tu też zależność zwrotna) na produktywności zaangażowanych czynników produkcji. Zatem, nie określając głębszego związku przyczynowo-skutkowego, analizujemy także relacje produktywnościowe związane z tymi czynnikami wytwórczymi. Celem jest zobrazowanie tych relacji produktywnościowych oraz różnic występujących w tym zakresie w rolnictwie krajów UE z uwzględnieniem podziału na „nowe" i „stare” kraje członkowskie.

Analizowane empirycznie relacje czynnikowe i produktywnościowe mają charakter niemal podręcznikowy. Przywołujemy pojęcia i prawidłowości ekonomiki rolnictwa (Grabowski 1986; Woś, Tomczak 1983; Tomczak, Rajtar 1973). Ujmiemy je po nowemu w proste zapisy analityczne, u których podstaw teoretycznych leży koncepcja zagregowanej analitycznej rolniczej funkcji produkcji. Przedstawione podejście i analiza mają znaczenie głównie poznawcze. To jednak pozwala objaśniać wyniki ekonomiczne obserwowane na powierzchni zjawisk. Nie stawiamy tu konkretnej hipotezy badawczej, chcemy jedynie zilustrować pewne ogólne zjawiska, potwierdzić występowanie uznanych w ekonomice rolnictwa prawidłowości w obecnych okolicznościach. Nie wykorzystujemy też metod przekraczających problem. Przy okazji celem jest pokazanie przydatności danych Rachunków Ekonomicznych dla Rolnictwa (RER) dla bardziej teoriopoznawczych analiz ekonomicznych.

\section{2. Źródła danych}

W pracy wykorzystano rachunki ekonomiczne dla rolnictwa (RER) - Economic Accounts for Agriculture (EAA), statystykę rolniczych nakładów pracy - Agricultural

1 Kraje nowo przyjęte po 2004 r. to: Cypr, Estonia, Litwa, Łotwa, Malta, Polska, Republika Czeska, Słowacja, Słowenia i Węgry, natomiast w 2007 r. przystąpiły Bułgaria i Rumunia, a w 2013 r. Chorwacja.

2 Kraje tworzące Unię Europejską przed akcesją nowych członków w 2004 r. Są to: Austria, Belgia, Dania, Finlandia, Francja, Grecja, Hiszpania, Holandia, Irlandia, Luksemburg, Niemcy, Portugalia, Szwecja, Wielka Brytania i Włochy.

3 Rozpoznane zróżnicowanie między państwami UE pod względem wielu warunków, np. przyrodniczych, jakości gleby, kierunków produkcji, innowacji, struktury i koncentracji, poziomu nawożenia i mechanizacji, intensywności rolnictwa, osiągniętego poziomu rozwoju gospodarczego oraz czynnika instytucjonalnego w publikacjach: Martín-Retortillo, Pinilla 2012; Baer-Nawrocka, Markiewicz 2010, 2013, może mieć wpływ na zróżnicowanie analizowanych relacji czynnikowych. 
Labour Input (ALI) oraz dostępne dane badania struktury gospodarstw rolnych Farm Structure Survey (FSS). Ze względu na to, że Badania struktury gospodarstw rolnych przeprowadzane są tylko co kilka lat ${ }^{4}$, niniejsze badanie ograniczono do lat 2005 i 2016. W badaniu z RER wykorzystano całkowitą produkcję sektora rolnego ${ }^{5}$ (output of the agricultural 'industry') wyrażoną w cenach bazowych ${ }^{6}$. Wartość zużycia środków trwałych (amortyzacja) (fixed capital consumption) oraz zużycie środków pośrednich (total intermediate consumption) zostały wyrażone w milionach euro i w cenach z 2005 r. Suma tych pozycji w badaniu odpowiada czynnikowi kapitału zaangażowanemu w proces produkcji. Z ALI wykorzystano całkowite nakłady pracy ${ }^{7}$ (total labour force input) wyrażone w tysiącach $\mathrm{AWU}^{8}$. Natomiast z FSS wykorzystano powierzchnię UR (utilised agricultural area) wyrażoną w hektarach. Ponieważ rachunki ekonomiczne dla rolnictwa dotyczą całego sektora rolnego i sporządzane są według jednolitej metodologii ${ }^{9}$ opracowanej przez

4 Dostępne dane dotyczą lat: 2005, 2007, 2010, 2013 i 2016.

5 Całkowita produkcja sektora rolnego (output of the agricultural 'industry') jest to suma produkcji rolniczej roślinnej i zwierzęcej, usług rolniczych oraz drugorzędnych nierozdzielnych działalności, która dotyczy przetwarzania produktów rolniczych, wyprodukowanych w gospodarstwach rolnych, których procesu produkcji nie da się oddzielić od procesu przetwarzania, np. przetwórstwo mleka, agroturystyka.

6 Ceny bazowe w RER to kwota, jaką otrzymuje producent rolny od nabywcy za jednostkę produktu, pomniejszona o ewentualne podatki od produktu, a powiększona o subwencje do produktu otrzymywane przez producenta.

7 Nakłady pracy w rolnictwie to praca opłacana (praca pracowników najemnych stałych i dorywczych) oraz praca nieopłacana (praca członków rodziny i pomoc sąsiedzka).

8 Roczna jednostka pracy (AWU) oznacza ekwiwalent pełnego etatu. Oblicza się ją przez podzielenie liczby godzin przepracowanych $\mathrm{w}$ ciągu roku przez roczną liczbę godzin odpowiadającą pełnemu etatowi. W Polsce zastosowano jednostkę pracy równą 2120 godzin pracy w roku, tzn. 265 dni roboczych po 8 godzin pracy dziennie. Przy wyliczaniu nakładów pracy wyrażonych w AWU (zgodnie z metodologią Eurostatu) zachowano warunek, że na jedną osobę nie może przypadać więcej niż 1 AWU, nawet jeżeli w rzeczywistości pracuje ona dłużej.

9 Metodologia rachunków ekonomicznych dla rolnictwa dostępna jest na stronie Eurostat: http:// ec.europa.eu/eurostat/cache/metadata/en/aact_esms.htm. RER są opracowywane dla całego rolnictwa bez względu na formę organizacyjno-prawną gospodarstwa. Cechą charakterystyczną RER jest przygotowanie ich według zasady memoriałowej, tj. w momencie zaistnienia zdarzenia gospodarczego, kiedy wartość ekonomiczna produktu jest tworzona, a nie w chwili, kiedy płatność jest rzeczywiście dokonywana (zasada kasowa). Rachunki ekonomiczne dla rolnictwa składają się ze spójnego i zintegrowanego systemu rachunków makroekonomicznych: produkcji, dochodów, dochodu „przedsiębiorcy rolnego" oraz zawierają elementy rachunku kapitałowego. Kluczową funkcją RER jest ustalenie dochodu rolniczego tworzonego w wyniku procesu produkcji rolnej całego sektora rolnego, a także w przeliczeniu na osobę $\mathrm{w}$ pełni zatrudnioną w rolnictwie. RER pozwalają na szczegółową analizę procesu produkcji rolniczej, która przedstawiana jest w wartościach pieniężnych. Ze względu na spójną metodologię sporządzania RER w krajach UE możliwe jest porównywanie sytuacji ekonomicznej rolnictwa pomiędzy krajami Wspólnoty. Rachunki mogą być również wykorzystywane do pomiaru udziału rolnictwa w gospodarce narodowej i w dochodzie unijnego rolnictwa. Przesłanką prowadzenia systemu RER, jako statystycznego systemu UE, były przede wszystkim monitoring i ewaluacja (WPR). RER pozwalają na prawie bieżące monitorowanie dochodów rolniczych. 
Eurostat, uprawnia je to do porównań sytuacji ekonomicznej rolnictwa pomiędzy krajami Wspólnoty.

\section{Ujęcie analityczne problemu}

Podstawą teoretyczno-metodologiczną analizy relacji czynnikowych i produktywnościowych jest koncepcja funkcji produkcji i teoria czynników produkcji oraz ich sprawności (Woś, Tomczak 1983; Tomczak, Rajtar 1973). Rozpoczynamy zatem od funkcji produkcji (Bezat-Jarzębowska, Rembisz 2018) zapisanej jako:

$$
y=f(Z, K, L, n)
$$

gdzie: $y$ - wielkość produkcji (końcowej); $Z$ - czynnik ziemia; $K$ - czynnik kapitału zaangażowanego $\mathrm{w}$ proces produkcji ${ }^{10} ; L-$ czynnik pracy zaangażowany $\mathrm{w}$ produkcję, $n$ - niematerialne czynniki mające wpływ na produkcję $y$, takie jak: zmiany klimatu, wykształcenie, organizacja, postęp, polityka rolna, ekonomiczna itp.

W badaniu nie omawiamy czynników niematerialnych. Przyjmujemy natomiast, że relacje między czynnikami ziemi, pracy i kapitału są w jakimś stopniu uwarunkowane nimi. Ich wpływ jest implicite ujmowany w relacjach produkcji do zaangażowanych wyodrębnionych w funkcji (1) materialnych czynników produkcji. Przesłanką teoretyczną do tego jest to, iż każdy producent rolny, podejmując decyzję o zaangażowaniu czynników produkcji w swoim gospodarstwie (przy uwzględnieniu ich jakości) w procesie produkcji, kieruje się swoją wiedzą i doświadczeniem, jak również bieżącą polityką rolną i ekonomiczną, klimatem politycznym, bezpieczeństwem i wieloma tymi niematerialnymi czynnikami $(n)$. Wspominamy tylko o tych czynnikach, ponieważ ma to określony, tu niebadany, wpływ na relacje czynnikowe, które są przedmiotem uwagi w tym artykule. W pierwszej grupie (A) analizowane są trzy relacje między czynnikami produkcji:

- $\left(\frac{K}{L}\right)$ - techniczne uzbrojenie pracy; relacja czynnika kapitału do czynnika pracy, jest to główne źródło warunkujące wydajność czynnika pracy (w tys. euro/AWU);

- $\left(\frac{Z}{L}\right)$ - relacja czynnika ziemi do czynnika pracy ilustruje strukturę agrarną, relacja ta tak samo jak poprzednia warunkuje wydajność czynnika pracy (w ha/ AWU);

10 Na potrzeby badania kapitał został wyrażony amortyzacją z RER (Fixed Capital Consumption). 
- $\left(\frac{K}{Z}\right)$ - relacja czynnika kapitału do czynnika ziemi ma podstawowy wpływ na produktywność tego ostatniego i charakteryzuje intensywność rolnictwa (w euro/ha).

Te relacje z grupy A warunkują wysokość relacji produktywnościowych ujętych w nich czynników produkcji ${ }^{11}$. Do ustalenia produktywności czynnika pracy, czynnika ziemi i czynnika kapitału, czyli cząstkowych mierników efektywności produkcji, przyjęto w liczniku wartość całkowitą produkcji sektora rolnego, a w mianowniku zaangażowanie wartościowe poszczególnych czynników wytwórczych. Mamy więc drugą grupę $(\mathbf{B})$ relacji:

- $\left(\frac{y}{K}\right)$ - produktywność czynnika kapitału warunkującą jego wynagrodzenie, np. w stosunku do stopy procentowej (w mln euro);

- $\left(\frac{y}{Z}\right)$ - produktywność czynnika ziemi warunkująca wynagrodzenie tego czynnika, np. poziom renty gruntowej (w euro/ha);

- $\left(\frac{y}{L}\right)$ - produktywność (wydajność) czynnika pracy warunkująca dochody $\mathrm{z}$ pracy w rolnictwie (w tys. euro/AWU).

$\mathrm{W}$ tym artykule przeanalizujemy jedynie, jak kształtują się poziomy tych relacji w obu grupach w rolnictwie krajów UE. W sposób syntetyczny obrazują one charakter rolnictwa i podstawy tego, co zwykle się pisze np. o konkurencyjności produkcji rolnictwa w różnych analizach porównawczych.

\section{Poziom relacji czynnikowych}

W tej części artykułu na rysunkach 1-3 przedstawiona została wizualizacja poziomu relacji czynnikowych w rolnictwie (grupa A) w latach 2005 i 2016. Są one uporządkowane względem poziomu danej relacji, a nie rolnictwa danego kraju. Porządkowanie następuje od najwyższego do najniższego poziomu danej relacji w 2005 r. Na rysunku 1 została przedstawiona pierwsza relacja obrazująca zaangażowanie czynnika kapitału w stosunku do czynnika pracy. Ta relacja w istocie (uzbrojenie techniczne pracy) jest rezultatem procesów substytucji czynnika pracy przez czynnik kapitału i przyjmowana jako ilustracja nowoczesności i technik kapitałochłonnych. Pierwsza obserwacja dotyczy państw, które przystąpiły do UE po 2004 r., znalazły się one po prawej stronie rysunku. Różnice w poziomie

11 Opis i dowód zależności między relacjami czynnikowymi (technicznymi) a relacjami produktywności w kontekście funkcji celu producenta jako podstawy wynagrodzeń czynników produkcji znajduje się w Rembisz 2008. 
tej relacji układają się niemal podręcznikowo. Można to oczywiście tłumaczyć niższym poziomem zaangażowania czynnika kapitału oraz relatywnie wyższym zaangażowaniem czynnika pracy (z wyjątkiem rolnictwa Czech), co implicite można wiązać z poziomem rozwoju gospodarczego danego kraju. Pod względem technicznego uzbrojenia pracy w 2016 r. sytuacja najlepiej (jeśli wyższy poziom uznajemy za lepszy) wyglądała w rolnictwie Danii, gdzie na jednego pełnozatrudnionego przypadało najwięcej kapitału (ok. 154 tys. euro/AWU) oraz w Holandii (118,6 tys. euro/AWU). Najgorsza sytuacja pod względem tego poziomu była obserwowana w Rumunii (5,7 tys. euro/AWU), w Polsce (7,1 tys. euro/AWU) i w Bułgarii (7,6 tys. euro/AWU). W Danii między rokiem 2005 a 2016 nastąpiła znaczna poprawa tej relacji, o ponad 45 tys. euro/AWU w ujęciu bezwzględnym. W państwach takich jak Holandia, Luksemburg, Niemcy czy Szwecja w 2016 r. analizowana relacja K/L zwiększyła się o połowę mniej, tj. o ok. 21 tys. euro/AWU. Natomiast zmniejszenie wartości czynnika kapitału na jednego pełnozatrudnionego odnotowano w czterech państwach: w Belgii (spadek o 12,4 tys. euro/AWU), na Malcie, Cyprze i w Irlandii. Oczywiście temu zróżnicowaniu poziomów technicznego uzbrojenia pracy winno odpowiadać zróżnicowanie co do wydajności tego czynnika, co omawiamy dalej (vide rysunek 6).

Mniej oczywiste jest ułożenie się danych, jeśli idzie o relację czynnika ziemia do czynnika pracy, co w dużym stopniu odzwierciedla strukturę agrarną państw (rysunek 2). Tu układ wykresu słupkowego nie łączy się w tak oczywisty sposób z podziałem na kraje nowe i stare UE, wiąże się bowiem trochę bardziej z poziomem rozwoju gospodarczego danego państwa. Można zauważyć, że ten wskaźnik jest wyraźnie wyższy w starych krajach UE, a więc w krajach o wyższym poziomie rozwoju gospodarczego. Największym uzbrojeniem czynnika pracy charakteryzowało się rolnictwo brytyjskie (57,3 ha/AWU) i szwedzkie (51,6 ha/AWU) oraz duńskie i estońskie. Najmniejszą liczbą hektarów użytków rolnych przypadającą na jednego pełnozatrudnionego charakteryzowały się państwa (pomijając Maltę i Cypr): Słowenia (6,1 ha/AWU), Rumunia (7,9 ha/AWU), Polska (8,6 ha/AWU) i Chorwacja (9,0 ha/AWU). Średnia ilość ha UR przypadająca na jednego pełnozatrudnionego w UE w 2016 r. wyniosła 18,3 ha, a w 2005 r. 13,5 ha, tj. wzrosła o 4,8 ha UR/1 AWU (o 35,7\%). Największym wzrostem liczby hektarów UR charakteryzowała się Estonia (wzrost z 21,9 ha do 48,9 ha na 1 AWU). Istotne zmiany zaobserwowano również w Bułgarii i na Łotwie ${ }^{12}$.

$12 \mathrm{Z}$ analizy danych źródłowych wynika, że w przypadku Estonii, Łotwy i Słowacji zmianę tę należy tłumaczyć prawie dwukrotnym spadkiem nakładów pracy, natomiast w Bułgarii prawie 2-krotnym wzrostem powierzchni UR i 2,5-krotnym spadkiem nakładów pracy w rolnictwie. Wzrost powierzchni UR był spowodowany przystąpieniem Bułgarii do UE i objęciem dopłatami UR. Spowodowało to włączenie nieużytków do uprawy, stąd wzrost powierzchni UR. 


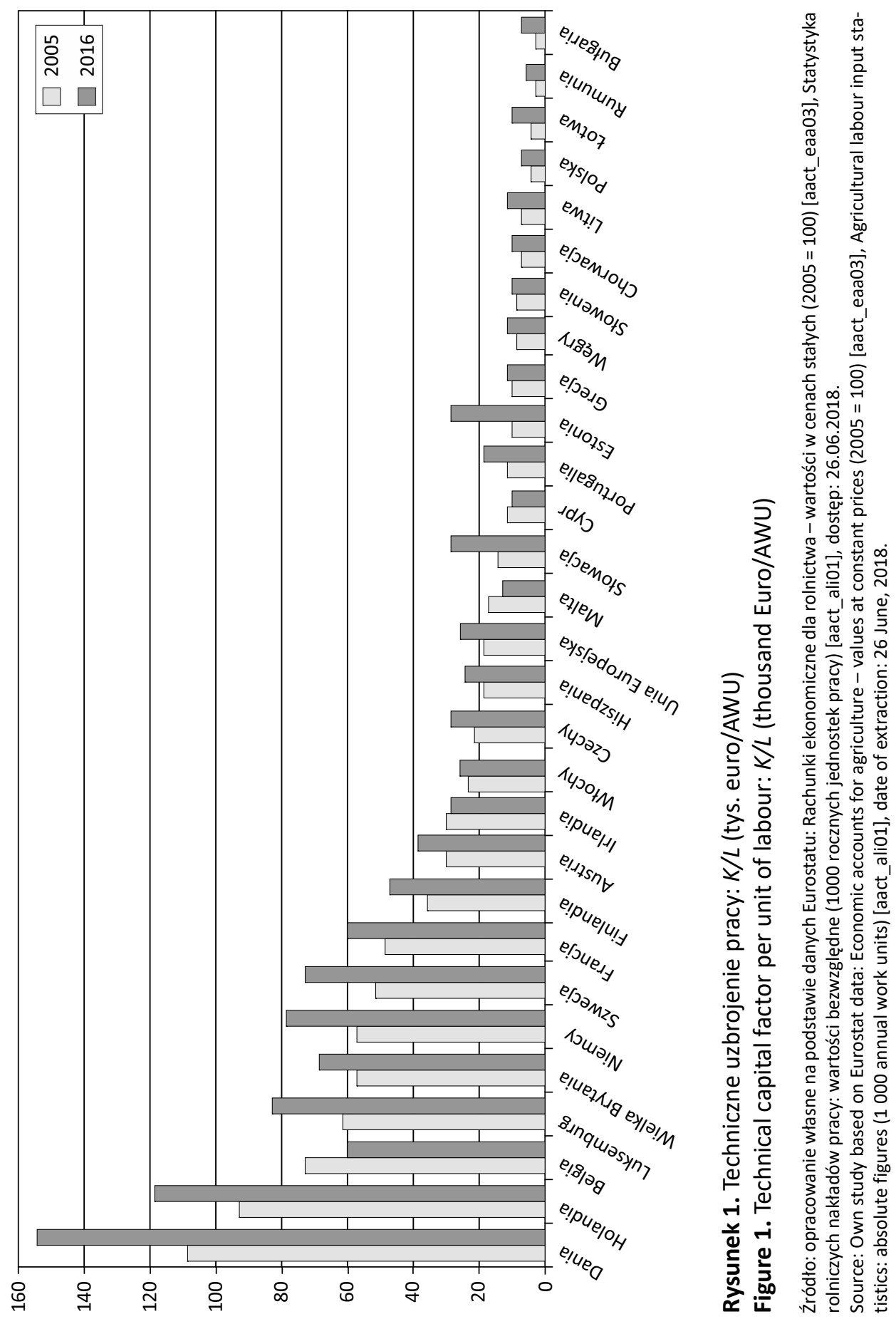




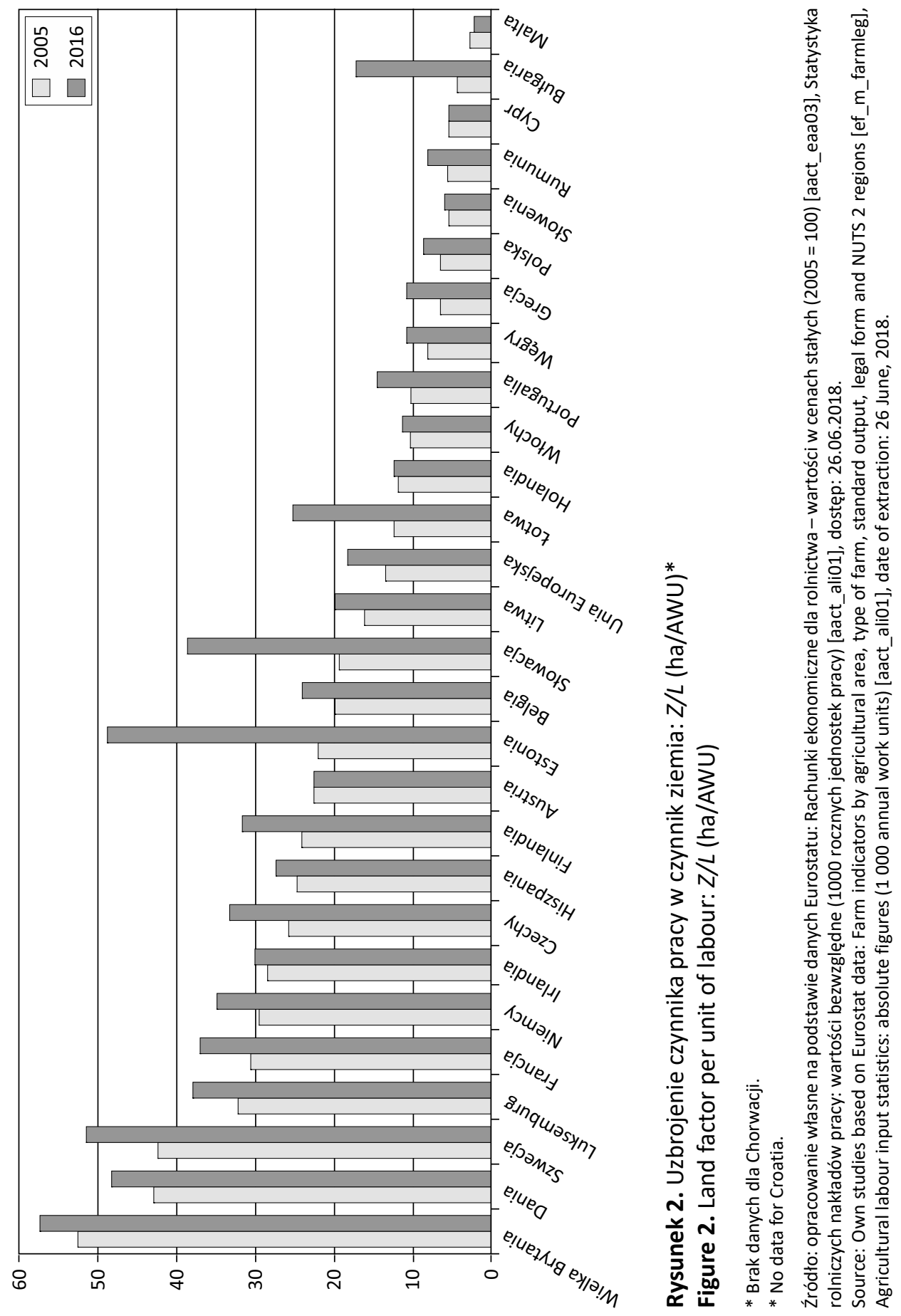



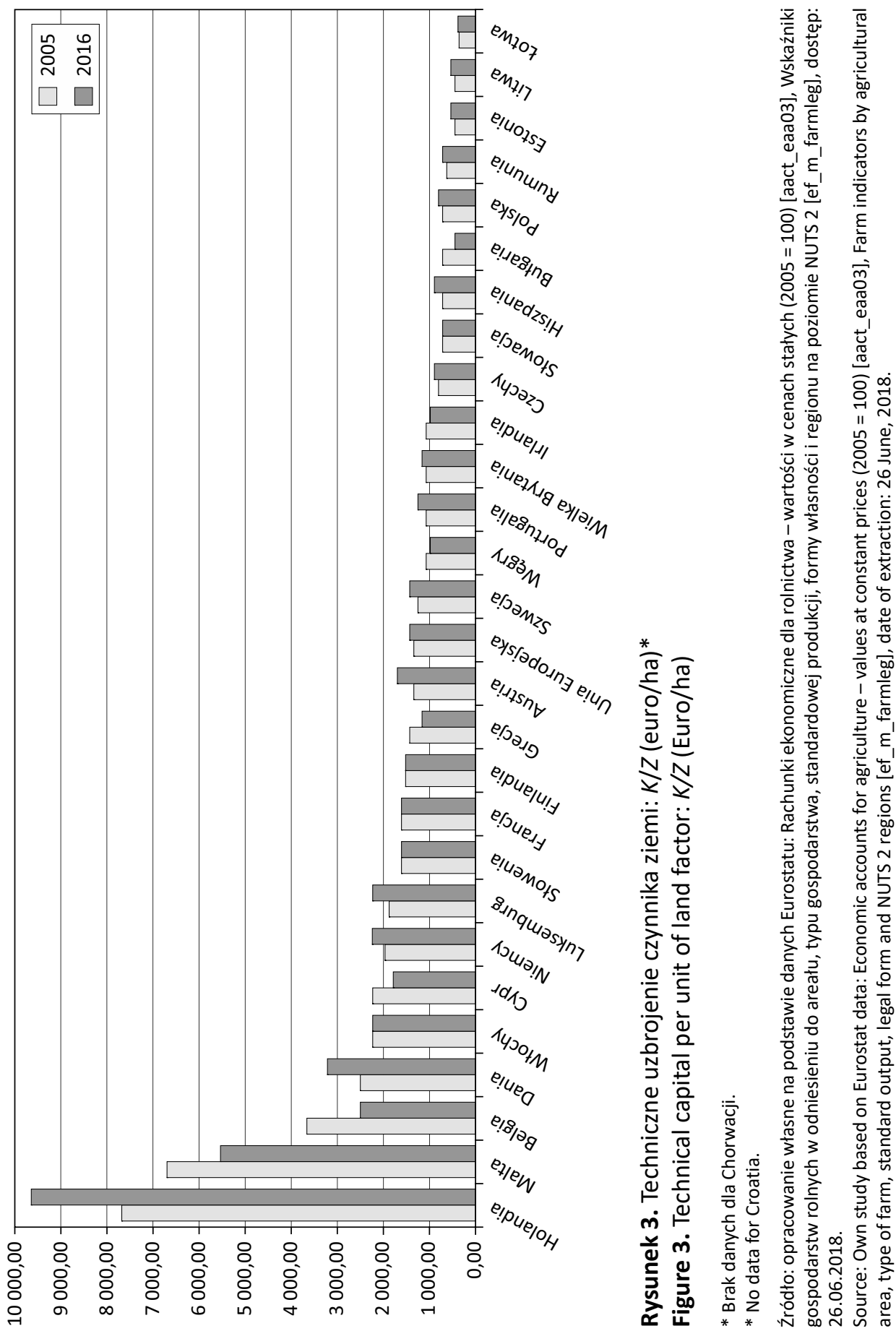
Najbardziej oczywistym wskaźnikiem chrakteryzującym intensywność rolnictwa (Woś, Tomczak 1983, s. 76-128; Tomczak, Rajtar 1973, s. 78-137) jest relacja czynnika kapitału do czynnika ziemia. Różnice wysokości tego wskaźnika pomiędzy rolnictwem krajów UE pokazano na rysunku 3. Poziom różnic w tym zakresie, $\mathrm{z}$ wyjątkiem dwu pierwszych krajów, jest na tle wcześniejszych dwu relacji stosunkowo najmniejszy. Również charakterystyczne jest to, że poziom tej relacji, a więc intensywności kapitałowej rolnictwa, nie zmieniał się znacznie, a jeśli już, to zmniejszał się $\mathrm{w}$ wielu krajach. Techniczne uzbrojenie ziemi w UE średnio w ujęciu bezwzględnym w 2016 r. wyniosło 1408,3 tys. euro/ha UR. W stosunku do 2005 r. poprawiło się o prawie 72 tys. euro/ha UR (o 5,4\%). Największą kapitałową intensywnością charakteryzowało się rolnictwo Holandii (9667,6 tys. euro/ ha UR) i Malty 5579,1 tys. euro/ha UR ${ }^{13}$. Spadki tej relacji odnotowano w rolnictwie wielu krajów, w tym największe, bo o ponad 30\%, w rolnictwie belgijskim i bułgarskim. Poza Holandią wzrost zaangażowanego czynnika kapitału w relacji do czynnika ziemia odnotowano w Danii, Austrii, na Litwie, Łotwie, również w Polsce - o prawie 19\%.

\section{Poziom relacji produktywnościowych}

Powyższym relacjom technicznym winny odpowiadać relacje produktywności ujętych w nich czynników produkcji (grupa B). Na rysunkach 4-6 przedstawione zostały relacje produktywnościowe od najwyższego do najniższego poziomu, a nie względem tego samego porządku krajów.

Różnice w pierwszej relacji produktywności (wydajności) czynnika pracy są zilustrowane na rysunku 4. Najważniejsza obserwacja jest taka, że podobnie jak poprzednio po lewej stronie są głównie kraje „starej” UE, a po prawej nowe 13 krajów UE. Odzwierciedleniem takiego układu państw na rysunku jest poziom w nich dochodów, ma to związek z zależnością między produktywnością pracy a dochodami per capita. Tak ujęty miernik produktywności pracy w UE wynosił 24,6 tys. w 2005 r., a w 2016 r. 35,8 tys. euro/AWU (wzrósł o 45,6\%). Również w prawie wszystkich analizowanych krajach produktywność czynnika pracy w rolnictwie poprawiła się. Wyjątkiem była tylko Malta - spadek produktywności o prawie $40 \%$. Najwyższą produktywnością czynnika pracy charakteryzowały się Dania i Holandia, oba te kraje uzyskały podobną wartość 161,4 tys. euro/AWU. Te dwa państwa znacznie zwiększyły również swoją wydajność pracy w badanym okresie (2005-2016), bo o ok. 36 tys. euro na jednostkę pracy. W 2016 r. tylko dwa kraje z tych, które zostały przyjęte do UE po 2004 r., uzyskały produktywność pracy przekraczająca

\footnotetext{
13 Przy czym na Malcie odnotowano spadek wartości tego wskaźnika o 17\% w latach 2005-2016.
} 


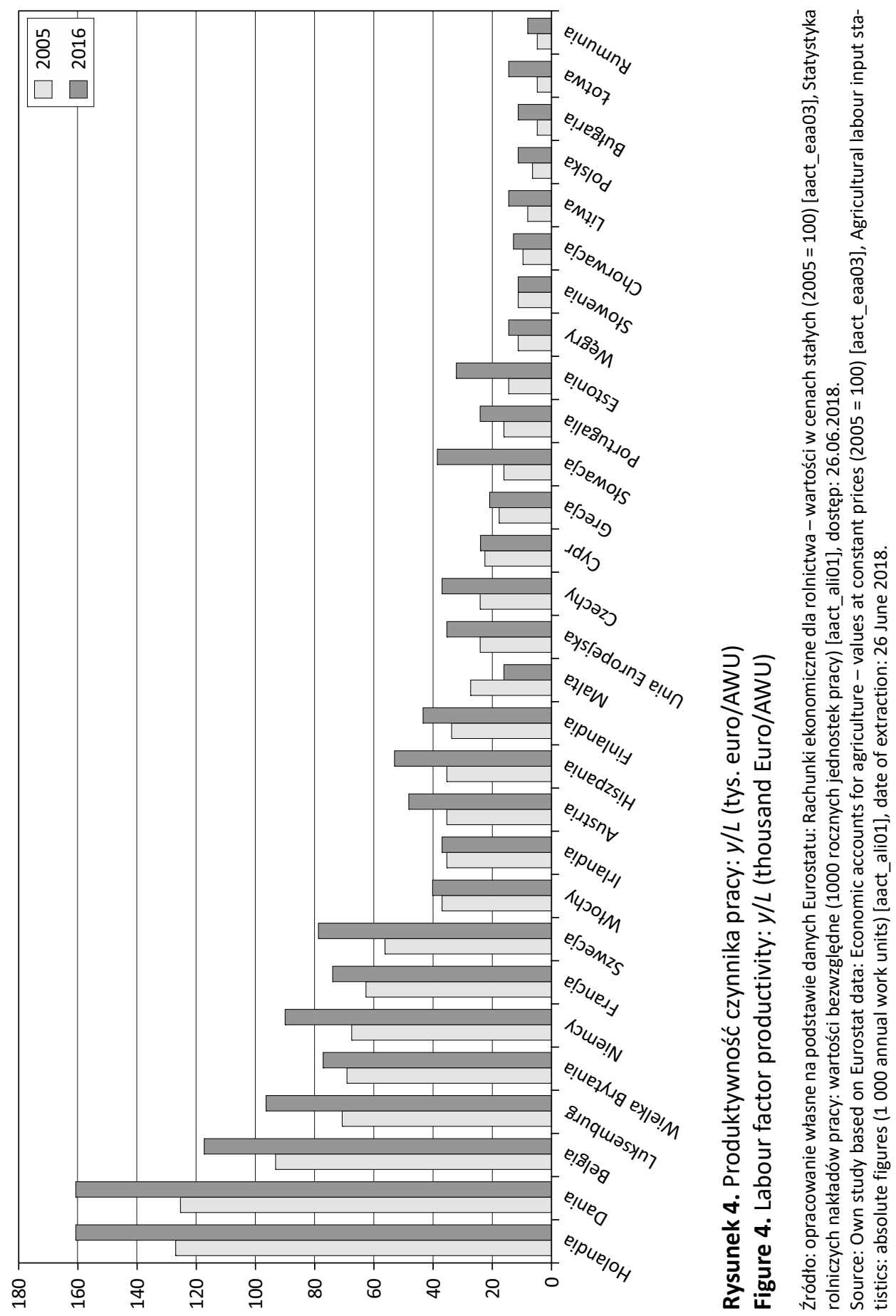



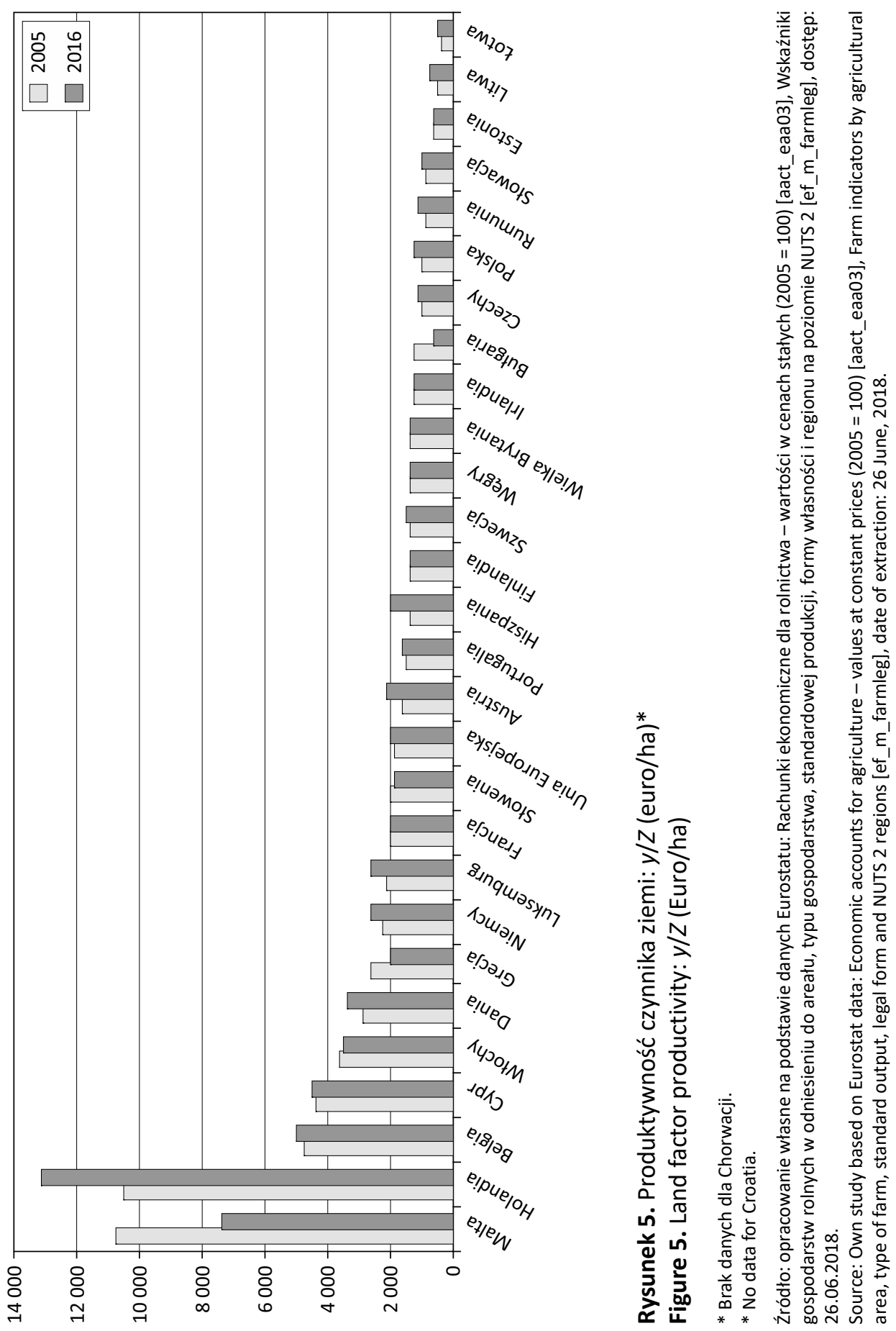


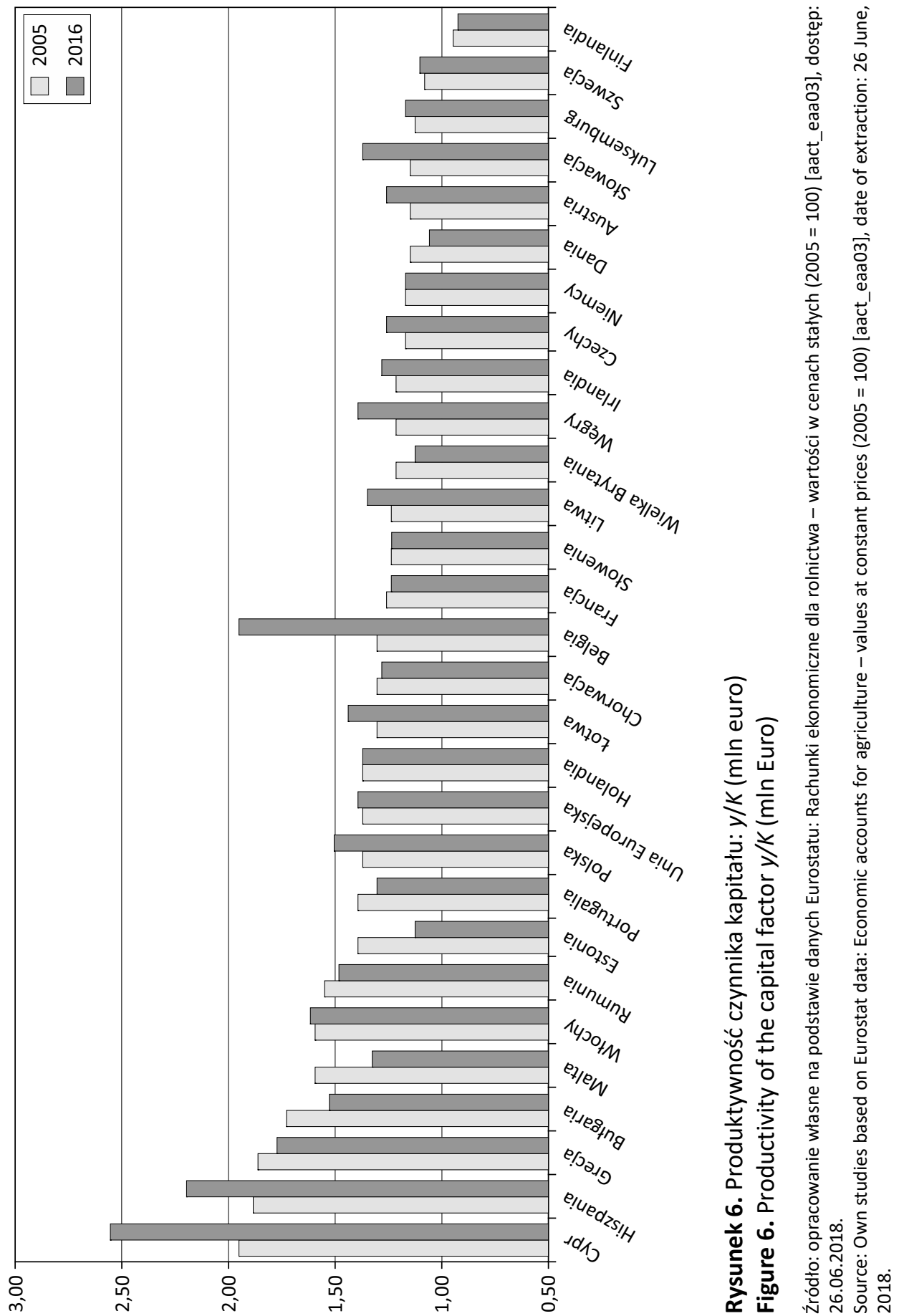


średnią wartość unijną, była to Słowenia (38,7 tys. euro/AWU) i Czechy (36,4 tys. euro/AWU). Pozostałe kraje charakteryzowały się wyraźnie niższą produktywnością pracy, w tym należy wymienić Polskę z wartością 10,7 tys. euro/AWU. Niższą produktywnością pracy uzyskała tylko Rumunia $(8,4$ tys. euro/AWU).

Drugim miernikiem wynikowym jest produktywność czynnika ziemi. W tym przypadku różnice między analizowanymi rolnictwami krajów UE są bardziej spłaszczone. Ponadto nie widać wyraźnych różnic w tym zakresie między starymi i nowymi krajami UE. Najwyższą produktywność czynnika ziemi, prawie 7-krotnie większą od średniej wartości UE w 2016, uzyskała Holandia - 13154 euro na hektar UR (rysunek 5). Przy pominięciu Malty i Cypru wysoką produktywnością charakteryzowała się również Belgia (4983,4 euro na hektar UR), ale już nie tak przeważającą w stosunku do rolnictwa pozostałych krajów. Holandia uzyskała też największy wzrost produktywności czynnika ziemi w badanych latach (2005-2016), o 2655 euro/ha UR. Niższą produktywnością czynnika ziemi charakteryzowało się rolnictwo krajów nowo przyjętych do UE, w tym szczególnie Łotwy, Estonii i Bułgarii.

Jeżeli idzie o produktywność czynnika kapitału w rolnictwie krajów UE, to różnice tu występujące nie cechują się czymś szczególnym. Różnice co do poziomów tak jak i samo zróżnicowanie między krajami są tu relatywnie małe. Podział na kraje „stare” i „nowe” UE w tym zakresie w zasadzie nie występuje. Odnotowano tu też najmniejszy przyrost tej produktywności między badanymi latami, bo o niecałe $2 \%$ (od 2005 r. do 2016 r.). Najwyższą produktywnością kapitału charakteryzowały się Cypr i Hiszpania (odpowiednio 2,55 i 2,19 mln euro).

\section{PKB per capita a relacje czynnikowe i produktywnościowe}

Powyższe wizualizacje pokazane na rysunkach 1-6 można zestawić, zgodnie $\mathrm{z}$ założeniem przyjętym we wprowadzeniu, z poziomem gospodarczym danego kraju, czego aproksymantą jest wskaźnik PKB per capita (rysunek 7). To traktujemy jako tło dla wnioskowania. $\mathrm{Z}$ prostego zestawienia tego rysunku z poprzednimi widać, że przyjęte założenie jest prawdziwe. Relacje czynnikowe grupy A oraz relacje produktywnościowe grupy B układają się zgodnie $\mathrm{z}$ tym, co pokazane jest na rysunku 7. Oznacza to implicite, że są one „zdeterminowane” przez poziom gospodarczy danego kraju mierzony tym wskaźnikiem. Potwierdzają to uznane prawidłowości z ekonomiki rolnictwa ujmowane w modelach Kuznetza, Lewisa i Haymi-Ruttena opisywane w powoływanych podręcznikach. Są to, jak wynika $\mathrm{z}$ tej analizy, prawidłowości uniwersalne o znamionach paradygmatów. 


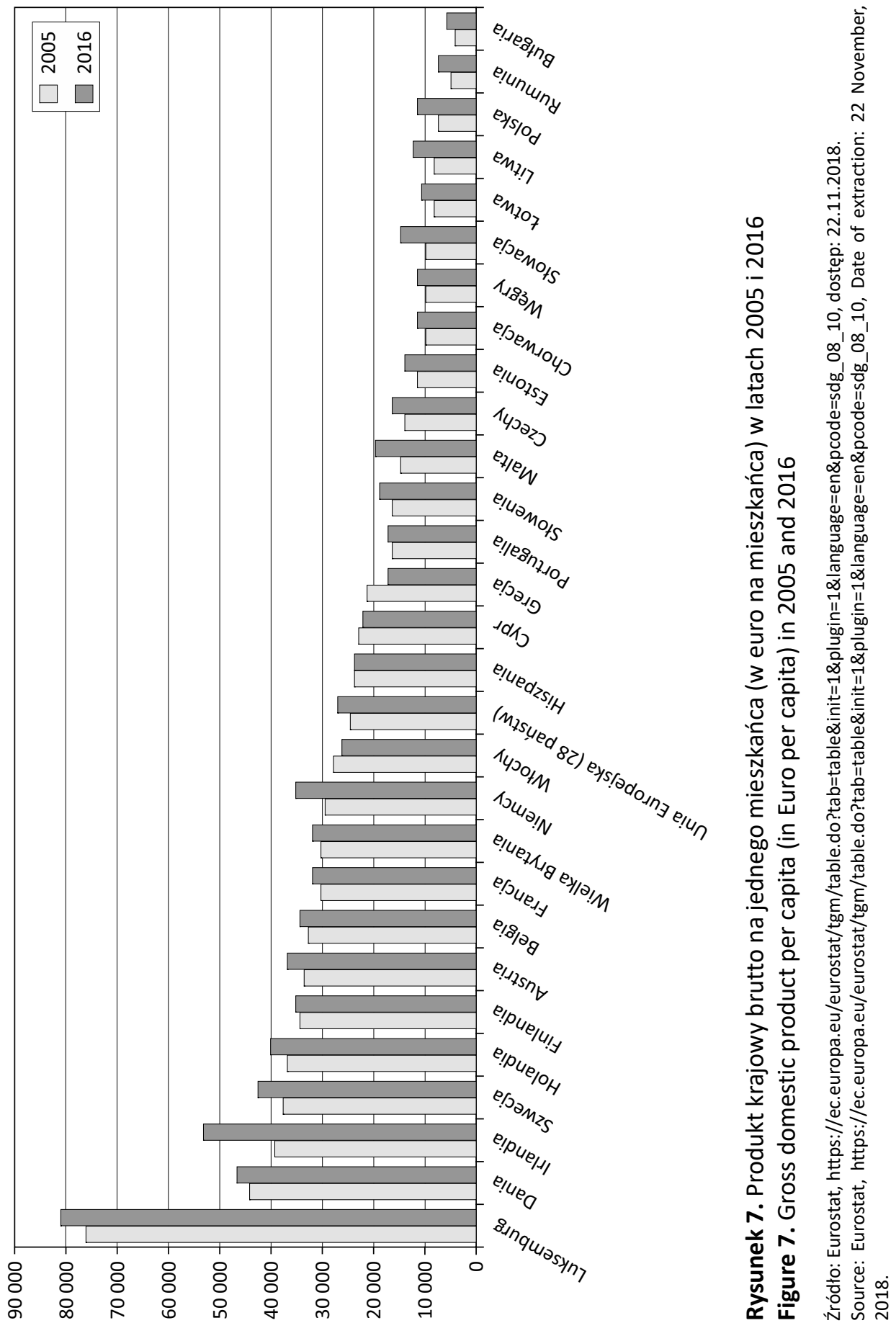




\section{Korelacja między relacjami czynnikowymi i produktywnościowymi}

By nieco poszerzyć podstawy do powyższego wnioskowania w kwestii powiązania między analizowanymi relacjami czynników a ich produktywnością, obliczono współczynnik korelacji Pearsona (tabela 1). Badania wykazały, że występuje dość silna zależność statystyczna między technicznym uzbrojeniem czynnika pracy a jego produktywnością, współczynnik korelacji mieścił się w przedziale 0,9-1,0. Oznacza to, iż wraz ze wzrostem relacji czynnika kapitału na jednostkę czynnika pracy rosła jego produktywność. Podobnie silna zależność wystąpiła między technicznym uzbrojeniem czynnika ziemi a jego produktywnością. Oznacza to, że wraz ze wzrostem zaangażowania czynnika kapitału na jednostkę czynnika ziemi rosła jego produktywność, co jest zgodne z założeniami teoretycznymi ${ }^{14}$. Co zaskakujące i niejako niezgodne z założeniami teoretycznymi i przyjmowanymi poglądami, korelację umiarkowaną w przedziale $(0,4-0,6)$ wykazano między relacją ziemi i nakładami pracy $(Z / L)$ a produktywnością czynnika pracy. Oznacza to, że wzrostowi wielkości UR na osobę pełnozatrudnioną w rolnictwie towarzyszył umiarkowany przyrost produktywności (wydajności) czynnika pracy. Między pozostałymi relacjami czynników produkcji a ich produktywnością nie wykazano zależności (wystąpiła korelacja ujemna). Przykładowym wnioskiem z tej analizy korelacyjnej może być wskazówka, iż źródeł wzrostu produktywności czynnika pracy, a co za tym idzie dochodów, należy upatrywać we wzroście uzbrojenia czynnika pracy i ziemi w czynnik kapitału, a dopiero w drugiej kolejności w poprawie struktury agrarnej w rolnictwie.

W tabeli 2 przedstawione korelacje analizowanych relacji czynnikowych i produktywnościowych odniesiono do odpowiednika poziomu gospodarczego danych państw, czyli PKB per capita. Wystąpiła wysoka korelacja technicznego uzbrojenia pracy $(K / L)$ i jej produktywności $(Y / L)$ ze wskaźnikiem PKB per capita oraz umiarkowana korelacja między wskaźnikiem $(Z / L)$ a poziomem $\mathrm{PKB}$ per capita. Pierwsze statystyki są zgodne z założeniami teoretycznymi i oczekiwaniami, ostatnia nie. W przypadku pozostałych relacji czynnikowych i produktywnościowych współczynniki korelacji były niskie. Ujemna korelacja relacji produktywności kapitału do PKB per capita może wskazywać na przeinwestowanie rolnictwa w miarę wzrostu poziomu gospodarczego. Relatywnie niska korelacja dla wskaźnika produktywności

14 Nie odnosimy się tutaj do prawa malejących przychodów z dodatkowego zaangażowanego czynnika kapitału przy implicite danych pozostałych relacjach czynników produkcji. 


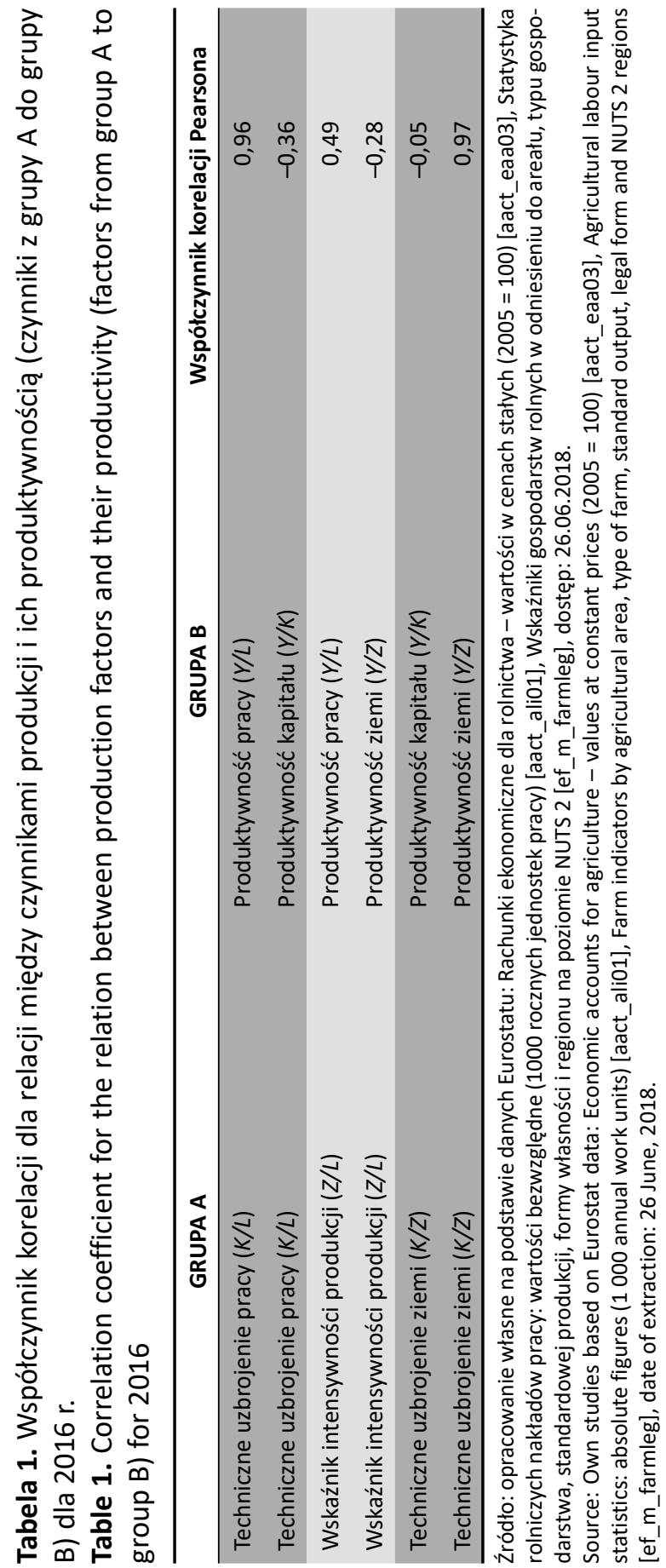




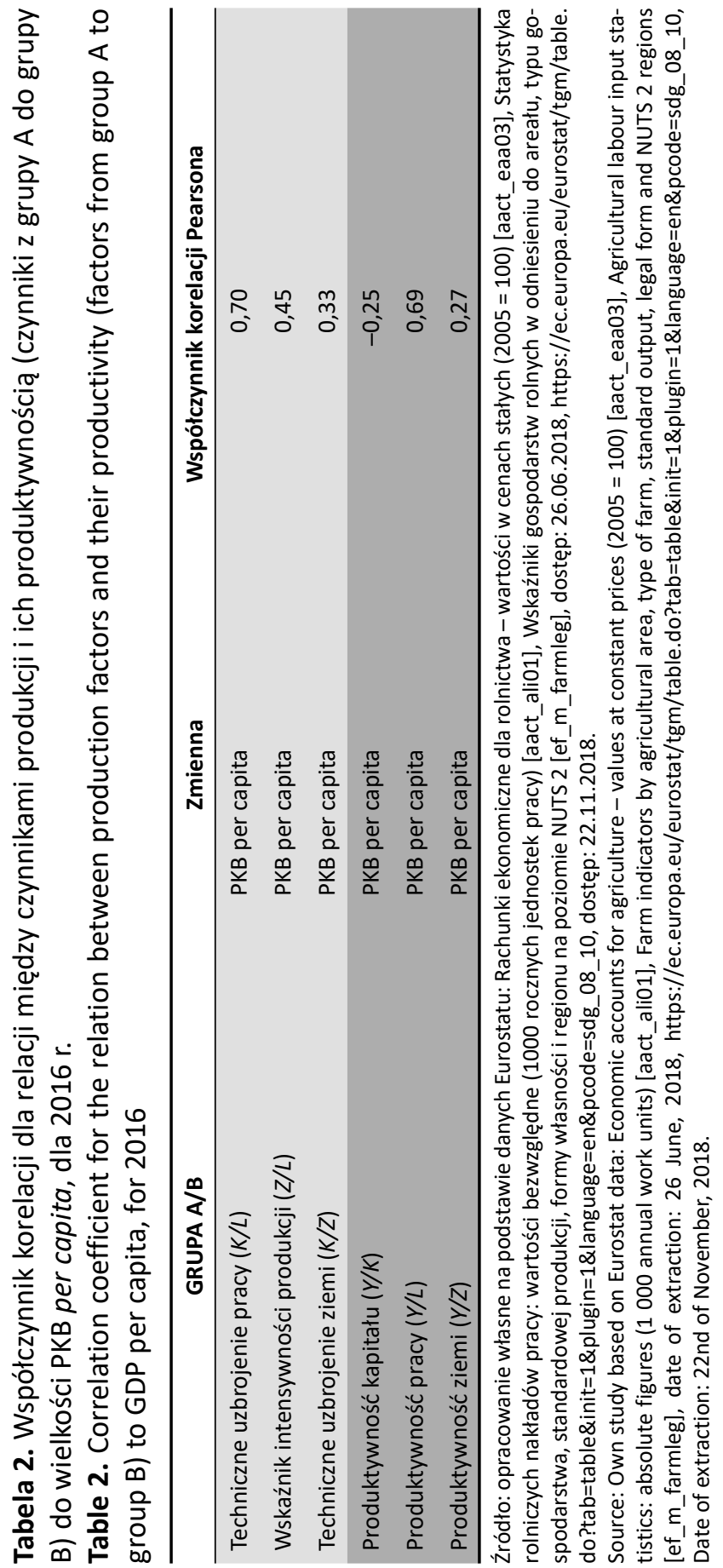


może oznaczać nawiązanie do prawidłowości malejącej produktywności czynnika ziemia. Wyjaśnienie przyczyn tych korelacji to osobne wyzwanie ${ }^{15}$.

\section{Podsumowanie}

Celem przyjętym w artykule było zilustrowanie i potwierdzenie uznanych w ekonomice rolnictwa prawidłowości co do relacji czynników produkcji i ich produktywności w rolnictwie w ostatnich latach w krajach UE. Punktem odniesienia był poziom gospodarczy oraz podział na kraje tzw. stare i nowe w UE. Cel ten osiągnięto. Podejście bazujące na teorii czynników produkcji i pojęciach technik wytwarzania oraz ich produktywności sprawdza się. Jest teoretycznie umocowanym syntetycznym ujęciem, za pomocą którego obrazuje się podstawy występujących różnic między rolnictwami krajów UE. W analizie ograniczono się do bezpośredniej interpretacji uzyskanych wizualizacji oraz prostych współczynników korelacji. $\mathrm{W}$ sensie merytorycznym przeprowadzona analiza potwierdza w większym bądź mniejszym stopniu większość formułowanych na gruncie teoretycznym prawidłowości co do relacji czynnikowych i produktywnościowych w kontekście poziomu rozwoju gospodarczego. W krajach starej UE na wyższym poziomie są zarówno relacje czynnikowe obrazujące nowoczesność i intensywność technik wytwarzania, jak i relacje produktywnościowe.

15 Zgodnie z tą prawidłowością w ekonomice rolnictwa następuje proces zastępowania czynników ziemi i pracy czynnikiem kapitału, oparty na zasadzie racjonalności gospodarowania, tj. zastępowania czynników o niższej czynnikami o wyższej produktywności (Woś, Tomczak 1983). Prawidłowość tę analizował Dionizy Niezgoda (1985), opisując zastępowanie pracy żywej przez nakłady pracy uprzedmiotowionej w miarę rozwoju społeczno-gospodarczego danego kraju z wykorzystaniem funkcji produkcji. 


\section{Aneks}

Podstawą analizy wymienionych wyżej relacji czynnikowych oraz produktywnościowych są dane zawarte w tabeli 3.

Tabela 3. Relacje czynników produkcji i ich produktywność w cenach stałych z roku 2005, bez dopłat do produktów

Table 3. Relation of production factors and their productivity in constant prices in 2005 , excluding subsidies on products

\begin{tabular}{|c|c|c|c|c|c|c|c|c|c|}
\hline \multirow[t]{2}{*}{ Wyszczególnienie } & \multicolumn{3}{|c|}{$\begin{array}{c}\text { Techniczne uzbrojenie } \\
\text { pracy } K / L \text { (tys. euro/AWU) }\end{array}$} & \multicolumn{3}{|c|}{$\begin{array}{l}\text { Wskaźnik intensywności } \\
\text { produkcji Z/L (ha/AWU) }\end{array}$} & \multicolumn{3}{|c|}{$\begin{array}{c}\text { Techniczne uzbrojenie ziem } \\
K / Z \text { (euro/ha) }\end{array}$} \\
\hline & 2005 & 2016 & $\begin{array}{c}2016 / \\
2005\end{array}$ & 2005 & 2016 & $\begin{array}{c}2016 / \\
2005\end{array}$ & 2005 & 2016 & $\begin{array}{c}2016 / \\
2005\end{array}$ \\
\hline $\begin{array}{l}\text { Kraje Unii Europejskiej } \\
\text { (bieżące zestawienie) }\end{array}$ & 18,0 & 25,7 & 143,0 & 13,5 & 18,3 & 135,7 & 1336,3 & 1408,3 & 105,4 \\
\hline Belgia & 72,2 & 59,8 & 82,8 & 19,8 & 23,6 & 119,0 & 3647,8 & 2538,7 & 69,6 \\
\hline Bułgaria & 3,1 & 7,6 & 245,4 & 4,4 & 17,4 & 399,3 & 711,7 & 437,3 & 61,4 \\
\hline Czechy & 20,8 & 28,7 & 138,3 & 25,6 & 33,1 & 129,4 & 812,5 & 868,4 & 106,9 \\
\hline Dania & 108,7 & 153,8 & 141,5 & 43,0 & 48,5 & 112,6 & 2524,5 & 3173,6 & 125,7 \\
\hline Niemcy & 56,8 & 77,9 & 137,0 & 29,2 & 34,8 & 119,1 & 1943,8 & 2236,0 & 115,0 \\
\hline Estonia & 9,8 & 27,9 & 283,9 & 21,9 & 48,9 & 223,3 & 448,0 & 569,5 & 127,1 \\
\hline Irlandia & 29,6 & 29,0 & 98,0 & 28,4 & 29,8 & 105,1 & 1041,0 & 970,1 & 93,2 \\
\hline Grecja & 9,4 & 12,1 & 128,7 & 6,6 & 10,6 & 161,0 & 1430,5 & 1143,9 & 80,0 \\
\hline Hiszpania & 18,4 & 24,5 & 133,0 & 24,4 & 27,4 & 111,9 & 752,8 & 894,4 & 118,8 \\
\hline Francja & 49,0 & 59,6 & 121,6 & 30,4 & 36,9 & 121,5 & 1613,5 & 1614,2 & 100,0 \\
\hline Chorwacja & 7,6 & 9,7 & 128,1 & b.d. & 9,0 & b.d. & b.d. & 1079,1 & b.d. \\
\hline Włochy & 22,9 & 24,6 & 107,3 & 10,2 & 11,2 & 109,9 & 2246,8 & 2194,0 & 97,7 \\
\hline Cypr & 11,7 & 9,4 & 81,0 & 5,3 & 5,4 & 101,7 & 2209,0 & 1759,9 & 79,7 \\
\hline Łotwa & 3,8 & 9,6 & 249,6 & 12,3 & 25,3 & 205,7 & 312,6 & 379,5 & 121,4 \\
\hline Litwa & 6,7 & 10,8 & 160,1 & 16,1 & 19,7 & 122,2 & 418,6 & 548,6 & 131,0 \\
\hline Luksemburg & 62,1 & 83,1 & 133,9 & 32,4 & 37,9 & 117,0 & 1918,5 & 2195,3 & 114,4 \\
\hline Węgry & 9,0 & 10,8 & 119,9 & 8,2 & 10,8 & 131,6 & 1 101,3 & 1003,2 & 91,1 \\
\hline Malta & 17,0 & 12,3 & 72,6 & 2,5 & 2,2 & 87,4 & 6716,1 & 5579,1 & 83,1 \\
\hline Holandia & 92,9 & 118,6 & 127,6 & 12,0 & 12,3 & 101,8 & 7711,8 & 9667,6 & 125,4 \\
\hline Austria & 30,7 & 38,2 & 124,4 & 22,3 & 22,6 & 101,5 & 1377,0 & 1688,0 & 122,6 \\
\hline Polska & 4,5 & 7,1 & 158,5 & 6,4 & 8,6 & 133,5 & 699,0 & 829,7 & 118,7 \\
\hline Portugalia & 10,9 & 18,0 & 165,2 & 9,9 & 14,5 & 146,3 & 1 100,3 & 1242,4 & 112,9 \\
\hline
\end{tabular}


Relacje czynnikowe i produktywnościowe w rolnictwie Unii Europejskiej

\begin{tabular}{|c|c|c|c|c|c|c|c|c|}
\hline \multicolumn{3}{|c|}{$\begin{array}{l}\text { Produktywność } \\
\text { kapitału } Y / K(\mathrm{~m} \mid \mathrm{n} \text { euro) }\end{array}$} & \multicolumn{3}{|c|}{$\begin{array}{c}\text { Produktywność ziemi } Y / Z \\
\text { (euro/ha) }\end{array}$} & \multicolumn{3}{|c|}{$\begin{array}{l}\text { Produktywność pracy } Y / L \\
\text { (tys. euro/AWU) }\end{array}$} \\
\hline 2005 & 2016 & $\begin{array}{l}2016 / \\
2005\end{array}$ & 2005 & 2016 & $\begin{array}{c}2016 / \\
2005\end{array}$ & 2005 & 2016 & $\begin{array}{c}2016 / \\
2005\end{array}$ \\
\hline 1,37 & 1,39 & 101,9 & 1827,7 & 1962,1 & 107,4 & 24,6 & 35,8 & 145,6 \\
\hline 1,30 & 1,96 & 151,5 & 4725,7 & 4983,4 & 105,5 & 93,5 & 117,4 & 125,5 \\
\hline 1,73 & 1,52 & 87,8 & 1229,6 & 663,6 & 54,0 & 5,4 & 11,5 & 215,5 \\
\hline 1,18 & 1,27 & 107,0 & 962,4 & 1100,5 & 114,3 & 24,6 & 36,4 & 147,9 \\
\hline 1,15 & 1,05 & 91,2 & 2904,9 & 3331,0 & 114,7 & 125,0 & 161,4 & 129,1 \\
\hline 1,18 & 1,16 & 98,7 & 2286,2 & 2594,9 & 113,5 & 66,8 & 90,4 & 135,2 \\
\hline 1,40 & 1,12 & 80,2 & 628,6 & 640,6 & 101,9 & 13,8 & 31,4 & 227,6 \\
\hline 1,21 & 1,29 & 106,7 & 1258,8 & 1251,2 & 99,4 & 35,7 & 37,3 & 104,5 \\
\hline 1,87 & 1,78 & 95,6 & 2668,5 & 2041,0 & 76,5 & 17,5 & 21,6 & 123,1 \\
\hline 1,89 & 2,19 & 115,9 & 1424,5 & 1961,2 & 137,7 & 34,8 & 53,6 & 154,1 \\
\hline 1,27 & 1,24 & 97,3 & 2049,9 & 1996,2 & 97,4 & 62,3 & 73,7 & 118,4 \\
\hline 1,30 & 1,29 & 99,0 & b.d. & 1389,8 & B.d. & 9,8 & 12,5 & 126,8 \\
\hline 1,59 & 1,62 & 102,1 & 3568,2 & 3555,8 & 99,7 & 36,4 & 39,8 & 109,5 \\
\hline 1,95 & 2,55 & 130,5 & 4317,3 & 4489,0 & 104,0 & 22,8 & 24,1 & 105,7 \\
\hline 1,30 & 1,44 & 110,5 & 407,3 & 546,4 & 134,1 & 5,0 & 13,8 & 275,9 \\
\hline 1,23 & 1,35 & 110,0 & 513,4 & 739,8 & 144,1 & 8,3 & 14,5 & 176,1 \\
\hline 1,13 & 1,17 & 103,1 & 2174,2 & 2564,8 & 118,0 & 70,4 & 97,1 & 138,0 \\
\hline 1,21 & 1,39 & 114,3 & 1336,4 & 1391,7 & 104,1 & 10,9 & 15,0 & 137,1 \\
\hline 1,59 & 1,33 & 83,5 & 10702,4 & 7421,8 & 69,3 & 27,0 & 16,4 & 60,6 \\
\hline 1,36 & 1,36 & 99,9 & 10499,2 & 13154,4 & 125,3 & 126,5 & 161,4 & 127,6 \\
\hline 1,15 & 1,27 & 110,8 & 1580,0 & 2146,5 & 135,9 & 35,2 & 48,5 & 137,8 \\
\hline 1,37 & 1,51 & 110,0 & 956,9 & 1249,1 & 130,5 & 6,2 & 10,7 & 174,3 \\
\hline 1,40 & 1,31 & 93,4 & 1543,4 & 1628,3 & 105,5 & 15,3 & 23,7 & 154,3 \\
\hline
\end{tabular}


Tabela 3-cd.

Table $\mathbf{3}$ - continued

\begin{tabular}{|c|c|c|c|c|c|c|c|c|c|}
\hline \multirow[t]{2}{*}{ Wyszczególnienie } & \multicolumn{3}{|c|}{$\begin{array}{c}\text { Techniczne uzbrojenie pracy } \\
K / L \text { (tys. euro/AWU) }\end{array}$} & \multicolumn{3}{|c|}{$\begin{array}{l}\text { Wskaźnik intensywności } \\
\text { produkcji Z/L (ha/AWU) }\end{array}$} & \multicolumn{3}{|c|}{$\begin{array}{c}\text { Techniczne uzbrojenie ziemi } \\
K / Z \text { (euro/ha) }\end{array}$} \\
\hline & 2005 & 2016 & $\begin{array}{c}2016 / \\
2005\end{array}$ & 2005 & 2016 & $\begin{array}{c}2016 / \\
2005\end{array}$ & 2005 & 2016 & $\begin{array}{c}2016 / \\
2005\end{array}$ \\
\hline Rumunia & 3,2 & 5,7 & 180,1 & 5,4 & 7,9 & 146,6 & 591,0 & 726,0 & 122,8 \\
\hline Słowenia & 8,8 & 9,6 & 108,9 & 5,4 & 6,1 & 113,3 & 1629,2 & 1566,3 & 96,1 \\
\hline Słowacja & 14,4 & 27,9 & 193,6 & 19,0 & 38,8 & 204,0 & 758,2 & 719,6 & 94,9 \\
\hline Finlandia & 35,6 & 47,0 & 132,1 & 23,9 & 31,5 & 131,6 & 1489,0 & 1494,5 & 100,4 \\
\hline Szwecja & 52,0 & 72,5 & 139,5 & 42,2 & 51,6 & 122,3 & 1230,7 & 1404,0 & 114,1 \\
\hline Wielka Brytania & 56,9 & 68,2 & 119,8 & 52,5 & 57,3 & 109,1 & 1083,4 & 1189,8 & 109,8 \\
\hline
\end{tabular}

b.d. - brak danych.

b.d. - no data.

Źródło: opracowanie własne na podstawie danych Eurostatu: Rachunki ekonomiczne dla rolnictwa - wartości w cenach stałych $(2005=100)$ [aact_eaa03], Statystyka rolniczych nakładów pracy: wartości bezwzględne (1000 rocznych jednostek pracy) [aact_ali01], Wskaźniki gospodarstw rolnych w odniesieniu do areału, typu gospodarstwa, standardowej produkcji, formy własności i regionu na poziomie NUTS 2 [ef_m_farmleg].

Source: Own study based on Eurostat data: Economic accounts for agriculture - values at constant prices (2005 = 100) [aact_eaa03], Agricultural labour input statistics: absolute figures (1 000 annual work units) [aact_ali01], Farm indicators by agricultural area, type of farm, standard output, legal form and NUTS 2 regions [ef_m_farmleg]. 
Relacje czynnikowe i produktywnościowe w rolnictwie Unii Europejskiej

\begin{tabular}{|c|c|r|r|r|r|r|r|r|}
\hline \multicolumn{3}{|c|}{$\begin{array}{c}\text { Produktywność } \\
\text { kapitału } Y / K \text { (mln euro) }\end{array}$} & \multicolumn{3}{c|}{$\begin{array}{c}\text { Produktywność ziemi } Y / Z \\
\text { (euro/ha) }\end{array}$} & \multicolumn{3}{c|}{$\begin{array}{c}\text { Produktywność pracy } Y / L \\
\text { (tys. euro/AWU) }\end{array}$} \\
\hline $\mathbf{2 0 0 5}$ & $\mathbf{2 0 1 6}$ & $\begin{array}{r}\mathbf{2 0 1 6 /} \\
\mathbf{2 0 0 5}\end{array}$ & $\mathbf{2 0 0 5}$ & $\mathbf{2 0 1 6}$ & $\begin{array}{r}\mathbf{2 0 1 6 /} \\
\mathbf{2 0 0 5}\end{array}$ & $\mathbf{2 0 0 5}$ & $\mathbf{2 0 1 6}$ & $\begin{array}{c}\mathbf{2 0 1 6 /} \\
\mathbf{2 0 0 5}\end{array}$ \\
\hline $\mathbf{1 , 5 4}$ & 1,48 & 95,9 & 910,9 & 1072,9 & 117,8 & 4,9 & 8,4 & 172,7 \\
\hline 1,23 & 1,23 & 99,5 & 2011,7 & 1923,7 & 95,6 & 10,8 & 11,7 & 108,3 \\
\hline 1,14 & 1,38 & 121,4 & 864,6 & 996,6 & 115,3 & 16,4 & 38,7 & 235,1 \\
\hline 0,94 & 0,93 & 99,5 & 1396,1 & 1394,3 & 99,9 & 33,4 & 43,9 & 131,4 \\
\hline 1,09 & 1,10 & 100,6 & 1342,4 & 1540,1 & 114,7 & 56,7 & 79,5 & 140,3 \\
\hline 1,22 & 1,13 & 92,9 & 1322,7 & 1350,1 & 102,1 & 69,5 & 77,4 & 111,4 \\
\hline
\end{tabular}




\section{Bibliografia}

Baer-Nawrocka A., Markiewicz N. (2010). Zróżnicowanie przestrzenne potencjału produkcyjnego rolnictwa w krajach Unii Europejskiej. Roczniki Nauk Rolniczych. Seria G-Ekonomika Rolnictwa, 97 (4), 9-15.

Baer-Nawrocka A., Markiewicz N. (2013). Relacje między czynnikami produkcji a efektywność wytwarzania w rolnictwie Unii Europejskiej. Journal of Agribusiness and Rural Development, 3 (29), 5-16.

Bezat-Jarzębowska A., Rembisz W. (2018). Mikroekonomia relacji czynników produkcji w rolnictwie: Ujęcie analityczne mechanizmów. Warszawa: Vizja Press \& IT.

EUROSTAT data, Economic accounts for agriculture - values at constant prices (2005 = 100) [aact_eaa03], Agricultural labour input statistics: absolute figures (1 000 annual work units) [aact_ali01], Farm indicators by agricultural area, type of farm, standard output, legal form and NUTS 2 regions [ef_m_farmleg] (dostęp: 26.06.2018).

Grabowski S. (1986). Analiza ekonomiczna w rolnictwie. Warszawa: Ludowa Spółdzielnia Wydawnicza.

https://ec.europa.eu/eurostat/tgm/table.do?tab=table\&init=1\&plugin=1\&language=en\&p code=sdg_08_10 (dostęp: 22.11.2018).

Martín-Retortillo M., Pinilla V. (2012). Why did Agricultural Labour Productivity not Converge in Europe from 1950 to 2005? EHES (European History Economic Society) Working Papers in Economic History, 25.

Niezgoda D. (1985). Substytucja między pracą żywą, ziemią i kapitałem w gospodarstwach indywidualnych. Annales Universitatis Mariae Curie-Skłodowska. Sectio H, Oeconomia, 19, 129-143.

Rembisz W. (2008). Mikro i makroekonomiczne podstawy równowagi wzrostu $w$ sektorze rolno-spożywczym. Warszawa: Vizja Press \& IT.

Tomczak F., Rajtar J. (1973). Ekonomika rolnictwa: Zarys teorii. Warszawa: Szkoła Główna Planowania i Statystyki.

Woś A., Tomczak F. (1983). Ekonomika rolnictwa: Zarys teorii. Warszawa: Państwowe Wydawnictwo Rolnicze i Leśne. 


\title{
Factor and Productivity Relations in EU Agriculture
}

\begin{abstract}
The article refers to the approach to the study of factorial and productivity relations that is recognised in agricultural economics. They have been defined analytically in a new way, starting from the production function. These relations have been analysed for EU countries implicitly for different economic levels. The aim was to demonstrate that the regularities associated with these relations are confirmed in the current stage of economic development of EU countries and are still a useful tool in the cognitive process. Moreover, they explain the basics of the current differences in agriculture in the EU member states, especially the so-called old and new ones. The EAA data were used for this purpose, thus indicating their usefulness for analysis.
\end{abstract}

Keywords: factor relations, factor productivity, Economic Accounts for Agriculture (EAA). 